\title{
Inferring global wind energetics from a simple Earth system model based on the principle of maximum entropy production
}

S. Karkar ${ }^{1, *}$ and D. Paillard ${ }^{1}$

${ }^{1}$ Laboratoire des Sciences du Climat et de l'Environnement, CEA-CNRS-UVSQ, Orme des Merisiers, Bât. 701, 91191 Gif-sur-Yvette CEDEX, France now at: LEMA-EPFL, Station 11, 1015 Lausanne, Switzerland

Received: 18 December 2014 - Accepted: 20 January 2015 - Published: 2 March 2015

Correspondence to: S. Karkar (sami.karkar@epfl.ch) and D. Paillard (didier.paillard@Isce.ipsl.fr)

Published by Copernicus Publications on behalf of the European Geosciences Union.

Wind energetics with a MEP climate model

S. Karkar and D. Paillard

Title Page

Abstract

Introduction

Conclusions References

Tables

Figures

14

$\Delta$

4

Back

Close

Full Screen / Esc

Printer-friendly Version

Interactive Discussion 


\section{Abstract}

The question of total available wind power in the atmosphere is highly debated, as well as the effect large scale wind farms would have on the climate. Bottom-up approaches, such as those proposed by wind turbine engineers often lead to non-physical results 5 (non-conservation of energy, mostly), while top-down approaches have proven to give physically consistent results. This paper proposes an original method for the calculation of mean annual wind energetics in the atmosphere, without resorting to heavy numerical integration of the entire dynamics. The proposed method is derived from a model based on the Maximum of Entropy Production (MEP) principle, which has proven to efficiently describe the annual mean temperature and energy fluxes, despite its simplicity. Because the atmosphere is represented with only one vertical layer and there is no vertical wind component, the model fails to represent the general circulation patterns such as cells or trade winds. However, interestingly, global energetic diagnostics are well captured by the mere combination of a simple MEP model and a flux inversion 15 method.

\section{Introduction}

Global available wind power for renewable energy production ultimately relies on geophysical considerations of the Earth system, as shown by Gustavson (1979). Whatever technological progress could be made on the design of wind turbines and wind farms, an upper limit is dictated, above all, by the maximum possible rate of conversion of available potential energy, which comes primarily from the Sun's differential heating, into kinetic energy - that is to say, winds.

Recent studies by Gans et al. (2010), Miller et al. (2011) and Marvel et al. (2012) have shown that the top-down approach, using Earth system models, despite an over-
ESDD

6, 407-433, 2015

Wind energetics with a MEP climate model

S. Karkar and D. Paillard

Title Page

Abstract Introduction

Conclusions References

Tables Figures

14 $>$ I

4

Back Close

Full Screen / Esc

Printer-friendly Version

Interactive Discussion 
power extractable from winds. Whereas the bottom-up method derived from the turbine engineering viewpoint lacks energy conservation on the global scale.

A wide variety of Earth system models exist, ranging from zero dimensional energy balance models, unidimensional to tridimensional box models with no dynamics, inter5 mediate complexity models, up to "IPCC-class" models. In the latter, the dynamics of the atmosphere, ocean, ice and biosphere, as well as the exchanges between these components, are computed by integration of the dynamical equations for one part, ad hoc parameterizations for another part, and coupling.

One important question remains: is it possible to devise the energetics of atmo10 spheric circulation, without computing the entire dynamics? Or, put differently: how far can we go, in terms of wind energetics, with a simple box model?

Paltridge (1975) is the first to propose a simple box model that relies on a maximization principle. Reformulated by O'Brien and Stephens (1995), the function to be maximized in this kind of model appears to be the entropy production rate, though it strongly resembles the conjecture of maximum generation of available potential energy of Lorenz (1960). This hypothesis (rather than a physical "principle"), gave very good results concerning the mean climate on Earth, especially concerning the surface temperature distribution. Models based on the maximum entropy production (MEP) have even shown to be in good agreement with the climate of other planet-like systems, such as Mars and Titan, as reported by Lorenz et al. (2001). For a review on the subject of global climate and the MEP principle, the reader is referred to Ozawa et al. (2003). Recently, Herbert et al. (2011) revisited these ideas and proposed a model that is both consistent with the MEP hypothesis and does not contain ad hoc parameterizations of the clouds. In their model, the only unknowns are the temperature and the convergence of energy fluxes in each cell, while they prescribed the radiative budget, the surface albedo, and the composition of the (dry) atmosphere. The only equations are energy balances (local and global), and a maximization of the total entropy production rate related to the diabatic heating.
ESDD

6, 407-433, 2015

Wind energetics with a MEP climate model

S. Karkar and D. Paillard

Title Page

Abstract Introduction

Conclusions References

Tables

Figures

14 $\rightarrow 1$

4

Back

Close

Full Screen / Esc

Printer-friendly Version

Interactive Discussion

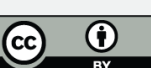


In this paper, we propose an original method for the calculation of mean annual wind energetics in the atmosphere, based on this MEP model.

The paper is organized as follows. In Sect. 2 we present the methods, hypotheses and equations of the model. In Sect. 3, we present the results and discuss their rele5 vance, in comparison with previous results from the literature. We conclude the paper in a final section where future developments of this model are proposed.

\section{Methods}

This section presents the necessary hypotheses and equations used successively in: the MEP climate model, the inference from divergences to fluxes, the computation of mean atmospheric winds.

\subsection{MEP climate model}

We use the box-model proposed by Herbert et al. (2011). This model is based on the hypothesis that all exchanges of energy in the Earth system, apart from the radiative exchanges, occur with the maximum possible rate of entropy production.

The Earth atmosphere is divided horizontally into $N=n_{\text {lat }} \times n_{\text {lon }}$ cells, following a latitude-longitude regular grid. Along the vertical, two levels are distinguished: the "ground" level, and the "atmosphere" level. Each cell is assumed to reach a local thermodynamic equilibrium. The $i$ th atmospheric cell has a temperature $T_{i}^{\text {a }}$ (respectively $T_{i}^{\mathrm{g}}$ for a ground cell), and is subject to an energy balance between the radiative fluxes 20 budget $R_{i}^{\mathrm{a}}\left(T_{i}^{\mathrm{a}}, T_{i}^{\mathrm{g}}\right)$ (resp. $R_{i}^{\mathrm{g}}\left(T_{i}^{\mathrm{a}}, T_{i}^{\mathrm{g}}\right)$ ) and the other forms of energy transport (for instance sensible and latent heat exchanges with neighboring cells) which are summed up into a term $d_{i}^{\mathrm{a}}$ (resp. $d_{i}^{\mathrm{g}}$ ) that stands for the divergence of energy fluxes in each box (per unit area, in $\mathrm{Wm}^{-2}$ ). The local energy balance, assuming stationary state, leads to $2 \mathrm{~N}$ equations of the form:
ESDD

$6,407-433,2015$

Wind energetics with a MEP climate model

S. Karkar and D. Paillard

Title Page

Abstract Introduction

Conclusions References

Tables Figures

14 $>$ I

4

Back

Close

Full Screen / Esc

Printer-friendly Version

Interactive Discussion 


$$
\left\{\begin{array}{l}
R_{i}^{\mathrm{a}}\left(T_{i}^{\mathrm{a}}, T_{i}^{\mathrm{g}}\right)-d_{i}^{\mathrm{a}}=0 \\
R_{i}^{\mathrm{g}}\left(T_{i}^{\mathrm{a}}, T_{i}^{\mathrm{g}}\right)-d_{i}^{\mathrm{g}}=0
\end{array}\right.
$$

where $i$ runs from 1 to $N$, and where the radiative budget has the following form:

$$
\left\{\begin{array}{l}
R_{i}^{\mathrm{a}}\left(T_{i}^{\mathrm{a}}, T_{i}^{\mathrm{g}}\right)=c_{i}^{\mathrm{a}, 0}+c_{i}^{\mathrm{a}, \mathrm{a}}\left(T_{i}^{\mathrm{a}}\right)^{4}+c_{i}^{\mathrm{a}, \mathrm{g}}\left(T_{i}^{\mathrm{g}}\right)^{4} \\
R_{i}^{\mathrm{g}}\left(T_{i}^{\mathrm{a}}, T_{i}^{\mathrm{g}}\right)=c_{i}^{\mathrm{g}, 0}+c_{i}^{\mathrm{g}, \mathrm{a}}\left(T_{i}^{\mathrm{a}}\right)^{4}+c_{i}^{\mathrm{g}, \mathrm{g}}\left(T_{i}^{\mathrm{g}}\right)^{4}
\end{array}\right.
$$

where the radiative coefficients $c_{i}^{X, y}$ are computed from the insolation, albedo, atmo5 spheric chemical composition, and atmospheric standard humidity profile of each grid cell (details of the radiative code can be found in Herbert et al., 2011).

Therefore, the rate of entropy production in an atmospheric cell is given by:

$\sigma_{i}^{\mathrm{a}}=-A_{i} \frac{d_{i}^{\mathrm{a}}}{T_{i}^{\mathrm{a}}}=-A_{i} \frac{R_{i}^{\mathrm{a}}\left(T_{i}^{\mathrm{a}}, T_{i}^{\mathrm{g}}\right)}{T_{i}^{\mathrm{a}}}$,

where $A_{i}$ is the surface of the grid cell. (The same formula applies to a ground cell, 10 substituting the superscript a with g.) The total rate of entropy production in the whole Earth system is then equal to:

$\sigma=-\sum_{i=1}^{N} A_{i}\left(\frac{R_{i}^{\mathrm{a}}\left(T_{i}^{\mathrm{a}}, T_{i}^{\mathrm{g}}\right)}{T_{i}^{\mathrm{a}}}+\frac{R_{i}^{\mathrm{g}}\left(T_{i}^{\mathrm{a}}, T_{i}^{\mathrm{g}}\right)}{T_{i}^{\mathrm{g}}}\right)$.

The last equation of the model is the global energy balance, which constrains the maximum of entropy production rate:

${ }_{15} e=\sum_{i=1}^{N} A_{i}\left(d_{i}^{\mathrm{a}}+d_{i}^{\mathrm{g}}\right)=0$.
ESDD

6, 407-433, 2015

Wind energetics with a MEP climate model

S. Karkar and D. Paillard

Title Page

Abstract

Introduction

Conclusions References

Tables

Figures

14

$\rightarrow 1$

4

Back

Close

Full Screen / Esc

Printer-friendly Version

Interactive Discussion 
The solution of our MEP problem is to find the temperature field $T_{i}$ (we now omit the superscript a or g) that maximizes $\sigma$ as given by Eq. (3), under the constrain $e=0$. It is sought by finding the minima of the Lagrange function:

$\mathcal{L}\left(\beta, T_{i}\right)=-\sigma-\beta e$

5 where $\beta$ is the Lagrange parameter associated to the global energy balance and has the dimension of the inverse of a temperature.

Finally, such minima are the solutions of the following system of $2 N+1$ nonlinear equations, that sums up the model's equations:

$$
\left.\begin{array}{l}
\frac{\partial R_{i}^{\mathrm{a}}}{\partial T_{i}^{\mathrm{a}}}\left(1 / T_{i}^{\mathrm{a}}-\beta\right)-\frac{R_{i}^{\mathrm{a}}\left(T_{i}^{\mathrm{a}}, T_{i}^{\mathrm{g}}\right)}{T_{i}^{\mathrm{a}}}+\frac{\partial R_{i}^{\mathrm{g}}}{\partial T_{i}^{\mathrm{a}}}\left(1 / T_{i}^{\mathrm{g}}\right)=0 \\
\frac{\partial R_{i}^{\mathrm{g}}}{\partial T_{i}^{\mathrm{g}}}\left(1 / T_{i}^{\mathrm{g}}-\beta\right)-\frac{R_{i}^{\mathrm{g}}\left(T_{i}^{\mathrm{a}}, T_{i}^{\mathrm{g}}\right)}{T_{i}^{\mathrm{g} 2}}+\frac{\partial R_{i}^{\mathrm{a}}}{\partial T_{i}^{\mathrm{g}}}\left(1 / T_{i}^{\mathrm{a}}\right)=0
\end{array}\right\} \forall i \in[1, N]
$$

where the $2 N+1$ unknowns are $\left(\beta,\left[T_{i}^{\mathrm{a}}, T_{i}^{\mathrm{g}}\right]_{1, N}\right)$.

\subsection{Energy transport: from divergence to heat fluxes}

\subsubsection{Principle}

Given the solution temperature field $T$ (from now on, we will drop the subscript $i$ and the superscript a/g), we can compute the divergence field $d$. Now, formally, given this scalar field $d$, the goal is to compute a vector field $F$ of energy fluxes, such that: $d=\operatorname{div} F$. To ensure unicity of the solution, we assume only one hypothesis, that $F$ is irrotational:

$\operatorname{rot} F=0$.
ESDD

6, 407-433, 2015

Wind energetics with a MEP climate model

S. Karkar and D. Paillard

Title Page

Abstract

Introduction

Conclusions References

Tables

Figures

14

$\rightarrow 1$

4

Back

Close

Full Screen / Esc

Printer-friendly Version

Interactive Discussion

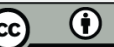


Note that this assumption does not imply that the velocity field be irrotational. Assuming that $F$ is irrotational is equivalent to assuming that it is the gradient of a scalar quantity $\Phi$. It corresponds somewhat to a local version of the second law of thermodynamics: the heat flux flows along the gradient of this scalar field (as it would flow from warm 5 to cold regions). A rotational part would transport heat along a loop, and therefore necessarily from cold regions to warm regions at some point. At this point, it seems a reasonable way to constrain $F$, knowing only its divergence $d$. If additional constraints were to be added (e.g. mechanical, hydrological...), this constraint could probably be released as the degeneracy on $F$ would disappear.

10 Then, we can compute $F$, via the pseudo-potential $\Phi$, which is obtained by inverting the Laplacian operator $\Delta$ :

$F=\operatorname{grad} \Phi=\operatorname{grad} \Delta^{-1} d$

\subsubsection{Construction of the Laplace operator}

Because this is a box-model, we need a discrete Laplace operator. Converting our grid 15 to a mathematical entity known as a graph, such a discrete operator exists and has the properties of the continuous Laplacian. In this equivalent graph, each grid cell of the model is a vertex (or node), and the edges represent the connections between grid cells.

There are $N$ atmospheric boxes in the model, each of which are connected to 4 ad20 jacent atmospheric boxes from the same level and to one ground box (except at the North and South poles where each box is connected to only 3 adjacent atmospheric boxes from the same level and one ground box). The connection graph on the ground level is different as it depends on the land-sea mask, because we assume that continents are not able to transport energy (or that it is negligible). Thus, two adjacent boxes
ESDD

$6,407-433,2015$

Wind energetics with a MEP climate model

S. Karkar and D. Paillard

Title Page

Abstract

Introduction

Conclusions References

Tables

Figures

14

$>$ I

4

Back

Close

Full Screen / Esc

Printer-friendly Version

Interactive Discussion 
an ocean box, or between two land boxes. Given a land fraction for each grid cell ${ }^{1}$, and applying a threshold at $1 / 2$, we obtain the land-sea mask, from which we construct the connection graph.

The positive discrete Laplacian operator on the graph $\mathcal{G}$ is defined as:

${ }_{5} \Delta=\mathbf{A}_{G}-\mathbf{D}_{G}$

where $\mathbf{D}_{\mathcal{G}}$ is the degree matrix of the graph (a diagonal matrix containing the degree of each vertex, i.e. the number of other vertices it is connected to), and $\mathbf{A}_{\mathcal{G}}$ the adjacency matrix (a matrix defined such that $\mathbf{A}_{\mathcal{G}}[i, j]=1$ if vertices $i$ and $j$ are connected, and $\mathbf{A}_{\mathcal{G}}[i, j]=0$ otherwise).

\subsubsection{Inversion of the divergence}

We are now able to compute the pseudo-potential $\Phi=\Delta^{-1} d$. Note that inverting the Laplace operator $\Delta$, in the case of a large number of grid cells, can be a cumbersome operation. However, being a large but sparse matrix, efficient algorithms exist to approximate the solution to $d=\Delta \Phi$ with very good accuracy, without the need for a full 15 matrix inversion (minimum residuals, and other iterative methods alike).

From this pseudo-potential $\Phi$, we can recover the flux field $F=\operatorname{grad} \Phi$. However, the vector field $F$ is only defined on the existing edges of the graph, that is, between two adjacent and connected cells of our grid. For two such cells, the flux of energy flowing from cell $i$ to cell $j$ is:

$20 \quad F_{i \rightarrow j}=\Phi[j]-\Phi[i]$.

\subsection{MEP winds}

From this point on, we will only use the temperature and fluxes that occur within the atmosphere layer. Therefore, we will write $T_{i}$ instead of $T_{i}^{\mathrm{a}}(i \in[1, N])$.

\footnotetext{
${ }^{1}$ We use the IPSL-CM4 grid at the $72 \times 96$ resolution and its land fraction mask, or interpolated versions of these two for different resolutions.
}

\section{ESDD}

$6,407-433,2015$

Wind energetics with a MEP climate model

S. Karkar and D. Paillard

Title Page

Abstract

Introduction

Conclusions References

Tables

Figures

14

$>$ I

4

Back

Close

Full Screen / Esc

Printer-friendly Version

Interactive Discussion

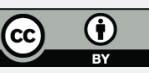




\subsubsection{Mass exchange rate}

All unresolved processes that lead to energy exchange (and entropy production) are supposed to be included in the term $d$. Thus, the interaction between two adjacent, connected cells $i$ and $j$ shall be entirely described by the flux $F_{i \rightarrow j}$. Assuming a dry 5 atmosphere, we use the hypothesis that all energy is exchanged as sensible heat. Taking into account mass conservation within the exchanges between the two cells, the same quantity of mass (per unit of time) $f_{i, j}$ is exchanged from cell $i$, with temperature $T_{i}$, to cell $j$, and from cell $j$, with temperature $T_{j}$ to cell $i$, the net budget in (sensible) heat exchange being $F_{i \rightarrow j}$ from the viewpoint of cell $i$. The mass exchange rate coefficient for these two cells $f_{i, j}$ is then defined as: $F_{i \rightarrow j}=c_{p} f_{i \rightarrow j}\left(T_{i}-T_{j}\right)$.

Under the hypotheses that $T_{i} \neq T_{j}$, comes the coefficient $f_{i, j}$ :

$f_{i, j}=\frac{F_{i \rightarrow j}}{c_{p}\left(T_{i}-T_{j}\right)}$.

Note that $f_{i, j}$ should always be positive since it represents a mass flux, and the corresponding energy should be directed from hot to cold. This constrain is not enforced in 15 this paper, and there are a few locations where mass fluxes are negative (also known as negative diffusion). A more rigorous approach would be to solve a constrained optimization problem, including the positivity constraint on $f_{i, j}$. Unfortunately, the associated numerical problem is far more difficult to solve. Empirically, there are only very few locations where $f_{i, j}<0$. This paper mainly addresses globally integrated energetic
ESDD

$6,407-433,2015$

Wind energetics with a MEP climate model

S. Karkar and D. Paillard

Title Page

Abstract

Introduction

Conclusions References

Tables

Figures

14

$>$ I

4

Back

Close

Full Screen / Esc

Printer-friendly Version

Interactive Discussion 


\subsubsection{Quasi-geostrophic flow}

\section{Hypotheses}

We assume that the atmosphere ${ }^{2}$ is composed of dry air, approximated as a perfect gas. We use the hydrostatic approximation along the vertical axis, and assume con5 stant sea level pressure. Orography is neglected.

\section{Equations}

The mean winds are then computed as a two-dimensional quasi-geostrophic flow $\boldsymbol{u}$, expressed using the vertical pressure coordinate, such that its zonal and meridional components $(u, v)$ satisfy:

$$
\left\{\begin{array}{l}
-2 m \Omega \sin \theta v=m R_{s} \log \left(\frac{p}{p_{0}}\right) \frac{\partial T}{\partial x}+\mathcal{F}_{\text {dissip }, x} \\
2 m \Omega \sin \theta u=m R_{s} \log \left(\frac{p}{\rho_{0}}\right) \frac{\partial T}{\partial y}+\mathcal{F}_{\text {dissip }, y}
\end{array}\right.
$$

where $\theta$ is the latitude, $m$ is the total mass of the air contained in the current grid cell, $p$ is the pressure at the barycenter of the cell, $p_{0}$ the reference pressure (here: the constant sea level pressure), $R_{\mathrm{s}}$ the specific gas constant for the air, and $\mathcal{F}_{\text {dissip }}$ is the dissipation term.

15 Given that we have assumed an exchange rate of mass for each pair of atmospheric cells, the same coefficient links the exchange rate of momentum. The dissipation term, for cell $i$, is then written:

$$
\mathcal{F}_{i, \text { dissip }}=-\sum_{j} f_{i, j}\left(\boldsymbol{u}_{i}-\boldsymbol{u}_{j}\right)
$$

\footnotetext{
${ }^{2}$ Here, we only intend to represent the vertical mean of the winds in the troposphere, however no hypothesis is made on the vertical structure.
}

\section{ESDD}

$6,407-433,2015$

Wind energetics with a MEP climate model

S. Karkar and D. Paillard

\section{Title Page}

Abstract Introduction

Conclusions References

Tables Figures

14 I

4

Back Close

Full Screen / Esc

Printer-friendly Version

Interactive Discussion 
where the sum excludes non-connected cells: $f_{i, j}=0$ is assumed for every pair of nonconnected cells. The sum also excludes cells from the ground layer: a null velocity field is assumed on the whole ground layer ${ }^{3}$.

Finally, the $2 N$ unknowns $\left(u_{i}, v_{i}\right)$ are solutions of the linear system of $2 N$ equations:

$5\left\{\begin{array}{l}-2 m_{i} \Omega \sin \theta_{i} v_{i}=m_{i} R_{\mathrm{s}} \log \left(\frac{p_{i}}{p_{0}}\right) \frac{\partial T_{i}}{\partial x}-\sum_{j} f_{i, j}\left(u_{i}-u_{j}\right) \\ 2 m_{i} \Omega \sin \theta_{i} u_{i}=m_{i} R_{\mathrm{s}} \log \left(\frac{p_{i}}{p_{0}}\right) \frac{\partial T_{i}}{\partial y}-\sum_{j} f_{i, j}\left(v_{i}-v_{j}\right)\end{array}\right.$.

\section{Results}

We present and discuss the results obtained with 2 vertical levels (ground and atmosphere) and a $36 \times 48$ regular grid (latitude, longitude). Other horizontal resolutions were tested, ranging from $18 \times 24$ to $96 \times 144$. Note that results do not always improve 10 with finer grids, as they do with most models, because cells too close to the equator lead to numerical instabilities (see discussion below).

\subsection{Temperature field}

Figure 2 shows the temperature field computed by the MEP model. As pointed out by Herbert et al. (2011), the result is in good agreement with the output of the IPSL-CM4 15 model, an IPCC-class Earth system model, except for a global positive bias mainly due to the lack of representation of water clouds in this model. The reader is referred to Herbert et al. (2011) for a more detailed review and discussion concerning the temperature field results.

\footnotetext{
${ }^{3}$ Unless surface currents were accounted for, but this is not the case here.
}

\section{ESDD}

$6,407-433,2015$

Wind energetics with a MEP climate model

S. Karkar and D. Paillard

Title Page

Abstract

Introduction

Conclusions References

Tables

Figures

14

I

4

Back

Close

Full Screen / Esc

Printer-friendly Version

Interactive Discussion 


\subsection{Heat flux}

Figure 3 shows the poleward meridional heat flux in the atmosphere. It is in good qualitative agreement with Trenberth and Caron (2001), but it lacks a factor of approximately 1.5 for good quantitative agreement. Herbert (2012) showed that the repartition

5 between oceanic and atmospheric transports in the MEP model suffers from the lack of representation of explicit dynamics. For instance, the model fails to represent the Atlantic meridional overturning circulation, which greatly affects the overall ocean heat transport, and consequently the atmospheric transport. However, given the simplicity of the MEP model, the qualitative agreement with known data and more elaborated models is remarkable.

Figure 4 shows a map of the vertical heat flux (positive downward). It is similar to the output of the IPSL-CM5A model, shown in Fig. 5, except in regions where the water cycle plays a dominant role: essentially over oceans at low latitudes.

\subsection{Annual mean winds}

15 The annual mean wind in the upper horizontal grid (atmospheric level) is shown in Fig. 6. The horizontal resolution shown here is $36 \times 48$. This annual mean wind is dominated by the geostrophic component, which results in a general West-wind trend with small fluctuations around land-ocean borders. The model fails to represent the main characteristics of the atmospheric circulation (westerlies, trade winds). This is not surprising since there is no vertical representation in our 1-layer atmosphere model, which therefore cannot represent Hadley or Ferrel cells. The global pattern is quite independent of the resolution, though strong variations occur near the equator.

The zonal mean of the annual mean wind speed, shown in Fig. 7, shows three peaks. Two peaks are located around $70^{\circ} \mathrm{S}$ (strong peak) and $70^{\circ} \mathrm{N}$ (moderate peak). The third one, near the equator, is dominant. However, it is believed to be due to spurious, unphysical, strong meridional components, as the computed winds tend to diverge near the equator.
ESDD

6, 407-433, 2015

Wind energetics with a MEP climate model

S. Karkar and D. Paillard

Title Page

Abstract

Introduction

Conclusions References

Tables

Figures

14 $\rightarrow 1$

4

Back

Close

Full Screen / Esc

Printer-friendly Version

Interactive Discussion 
The global average of the annual mean wind speed $\langle\|u\|\rangle$ is in the range 11.8$13.0 \mathrm{~m} \mathrm{~s}^{-1}$ (depending on the resolution). It is remarkable that variations of both the global mean, and the zonal mean distribution of the wind speed, are very small when the resolution changes.

5 The global average is consistent with most models and observations: for instance, available data from NCEP-R2 reanalysis by Kanamitsu et al. (2002) leads to a global average, annual mean value of $10.9 \mathrm{~m} \mathrm{~s}^{-1}$ for the wind speed (weighted average in the three spatial dimensions, simple mean along the time axis) on the period 1948present $^{4}$. IPSL-CM5A model historical simulation for the period $1950-2005^{5}$ gives an 10 annual mean, global average value of $10.1 \mathrm{~m} \mathrm{~s}^{-1}$.

\subsection{Winds energetics}

The detailed figures of winds derived from this simple model are not very reliable due to low resolution and lack of vertical representation, but some global quantities are. It is interesting to check if global values that are characteristics of wind energetics are also captured by the proposed model, as it is based on energy exchanges and thermodynamics. We thus focus on global means of three main energetic features: the global mean kinetic energy contained in the atmosphere (expressed in energy per unit surface), the global kinetic energy dissipation rate, and the kinetic energy dissipation rate inside the atmospheric boundary layer. The latter is especially interesting in the context of renewable energy: it is assumed to be the maximal power available for energy harvesting using surface-based wind farms.

\footnotetext{
${ }^{4}$ NCEP Reanalysis data provided by the NOAA/OAR/ESRL PSD, Boulder, Colorado, USA, from their Web site at http://www.esrl.noaa.gov/psd/, ftp://ftp.cdc.noaa.gov/Datasets/ncep. reanalysis.derived/pressure/wspd.mon.mean.nc.

${ }^{5}$ Historical simulation, part of the CMIP5 project, provided by IPSL: http://icmc.ipsl. fr/. Files used: http://dods.extra.cea.fr/store/p86caub/IPSLCM5A/PROD/historical/historical2/ ATM/Analyse/TS_MO_YE/historical2_19500101_20051231_1Y_vitu.nc (and "vitv").
}

ESDD

$6,407-433,2015$

Wind energetics with a MEP climate model

S. Karkar and D. Paillard

Title Page

Abstract

Introduction

Conclusions References

Tables

Figures

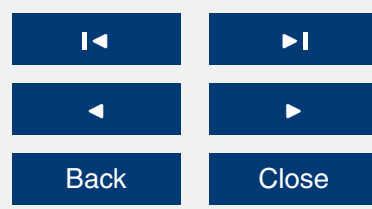

Full Screen / Esc

Printer-friendly Version

Interactive Discussion 
Note that the ranges given on the following values reflect the variations obtained when the resolution of the model is swept from $18 \times 24$ to $96 \times 144$.

\subsubsection{Global mean kinetic energy in the atmosphere}

The global mean kinetic energy of the atmosphere in the present model is in the 5 range $\langle K E\rangle=10-20 \times 10^{5} \mathrm{Jm}^{-2}$. It is a rather broad range, though the mean value $\left(14.3 \times 10^{5} \mathrm{~J} \mathrm{~m}^{-2}\right)$ is comparable with the values that were obtained using publicly available data of the NCEP-R2 reanalysis: $12.7 \times 10^{5} \mathrm{Jm}^{-2}$, or with that of the IPSL-CM5A historical simulation: $9.2 \times 10^{5} \mathrm{~J} \mathrm{~m}^{-2}$.

For comparison, the Lorenz cycles depicted in Marques et al. (2010) based on the 1979-2001 period for three different reanalyses also lead to similar values ${ }^{6}: 15.0 \times$ $10^{5} \mathrm{Jm}^{-2}$ for NCEP-R2, $16.2 \times 10^{5} \mathrm{Jm}^{-2}$ for ERA-40 (see Uppala et al., 2005), and $15.9 \times 10^{5} \mathrm{~J} \mathrm{~m}^{-2}$ for JRA-25 (see Onogi et al., 2007). On the other hand, Marvel et al. (2012) found in their study a very low value: $3.0 \times 10^{5} \mathrm{Jm}^{-2}$, while Miller et al. (2011) did not provide a value for the global kinetic energy.

\subsubsection{Kinetic energy dissipation rate in the whole atmosphere}

The total kinetic energy dissipation rate in our model is given by

$\langle D\rangle=\sum_{i} \boldsymbol{u}_{i} \cdot\left[\sum_{j} f_{i, j}\left(\boldsymbol{u}_{i}-\boldsymbol{u}_{j}\right)\right]$

and is found to be: $\langle D\rangle=1000-2500 \mathrm{TW}^{7}$.

Referring to Marques et al. (2010), values from reanalyses are 1415 TW for ERA40, 1316 TW for NCEP-R2, and 1372 TW for JRA-25. For comparison, Miller et al.

\footnotetext{
${ }^{6}$ When adding zonal and eddy kinetic energy, and averaging the four seasonal values for each quantity.

${ }^{7}$ It corresponds to $1.96-4.91 \mathrm{Wm}^{-2}$.
}

\section{ESDD}

$6,407-433,2015$

Wind energetics with a MEP climate model

S. Karkar and D. Paillard

Title Page

Abstract

Introduction

Conclusions References

Tables

Figures

14

$>$ I

4

Back

Close

Full Screen / Esc

Printer-friendly Version

Interactive Discussion 
(2011) found 950( \pm 110$)$ TW and Marvel et al. (2012) reports 1600 TW. The IPSL-CM5A historical simulation does not give access to this value ${ }^{8}$.

\subsubsection{Dissipation rate inside the atmospheric boundary layer}

In the context of wind turbines, the dissipation rate of kinetic energy in the whole atmo5 sphere is not of great interest, considering that wind turbines are surface structures, whether land-born or offshore. Moreover, the only vertical component in our model is the distinction between the ground level and the atmospheric level. Thus, it is interesting to check how the associated momentum drag, and its corresponding kinetic energy dissipation rate, compares with the dissipation rate of kinetic energy in the atmospheric boundary layer $(A B L)$ in more elaborated models.

In our model, the kinetic energy dissipated in the $A B L$ is given by

$D_{\mathrm{ABL}}=\sum_{i} \boldsymbol{\tau}_{i} \cdot \boldsymbol{u}_{i}$

where $\boldsymbol{\tau}_{i}=f_{i, j} \boldsymbol{u}_{i}$ when $i$ is an atmospheric cell and $j$ is the corresponding ground cell below.

15 We obtained $D_{\mathrm{ABL}}=400-800 \mathrm{TW}$, to be compared with the 513 TW for the ERA-40 reanalysis, reported by Miller et al. (2011), while they found 425 $( \pm 75)$ TW with their own model. Comparison is not possible with Marvel et al. as they did not provide this value, or with the IPSL-CM5A historical simulation ${ }^{9}$.

These main energetic features are illustrated in Fig. 8, where MEP refers to the present model, and is compared to the different reanalyses and models cited above.

\footnotetext{
${ }^{8}$ There is no track of the momentum drag coefficient, nor of the turbulent kinetic energy dissipated by the numerical scheme and it is quite complicated to reconstruct all these quantities.

${ }^{9} \mathrm{~A}$ simple $\boldsymbol{\tau} . \boldsymbol{u}_{10 \mathrm{~m}}$ computation gave $142 \mathrm{TW}$, which seems very low. The authors believe that it is not accurate. For the actual computation of what was dissipated in the ABL during the simulation, one needs to know the momentum drag coefficient, whose value is not constant and not easily accessible.
}

ESDD

6, 407-433, 2015

Wind energetics with a MEP climate model

S. Karkar and D. Paillard

Title Page

Abstract Introduction

Conclusions References

Tables Figures

14 $>1$

4

Back

Close

Full Screen / Esc

Printer-friendly Version

Interactive Discussion 


\section{Discussion}

The MEP model wind formulation suffers from several flaws that prevent it from getting a good picture on a regional basis. Specifically, spurious, strong meridional (and sometimes, zonal) components occur near the equator, showing a great variability when the 5 resolution changes. This high variability seem to result from a numerical instability around the equator: it is linked to our formulation for the flux $f_{i, j}$ (Eq. 11) which becomes divergent when temperature gradients are very small. It is probably necessary to represent explicitly latent heat fluxes in this region to avoid such a difficulty. Note that the problem is even worse when a finer resolution is used, as cells with the lowest lati-

with respect to the spatial resolution.

Considering the various energetic diagnostics, we notice a rather broad range for all values, with high center values. This overestimation of energy content and, more importantly, energy dissipation rates may be caused by the lack of water cycle in the 15 model. All energy fluxes are supposed to be sensible heat exchanges, which results in mass exchange rate coefficients $f_{i, j}$ that could be overestimated up to a factor 2 . This, in turn, would overestimate the ageostrophic component of the winds, responsible for the generation and dissipation of kinetic energy.

Nevertheless, given the spread of the values found in the literature, the energetics of the atmosphere-ground interface and of the vertically integrated winds seem to have been surprisingly well captured by the proposed model, despite its simplicity.

\section{Conclusions}

Because the current version of the model is two-dimensional (horizontal), the velocity field is unable to reproduce the well-known Hadley, Ferrel and Polar cells that characterize the general circulation in the atmosphere. However, the proposed model agrees with reanalysis data and IPCC-class ESMs in terms of wind energetics.
ESDD

$6,407-433,2015$

Wind energetics with a MEP climate model

S. Karkar and D. Paillard

Title Page

Abstract Introduction

Conclusions References

Tables Figures

14 $>$ I

4

Back

Close

Full Screen / Esc

Printer-friendly Version

Interactive Discussion 
Therefore, the general idea of the applying MEP principle to the earth system seems most appropriate for climate studies.

The model could be improved, especially by using a 3-D atmospheric grid, together with orography, a representation of a basic water cycle, and a seasonal cycle. Ongoing works are directed toward these improvements.

Other refinements such as advection could also be added to this model. However, the added value of including more explicit processes in the equations will have to be balanced with the added complexity of the model, given the general philosophy of this model which consists in modelling as few processes as possible and computing the 10 contribution of all unresolved processes using the MEP principle.

From such a basic level of simplicity, it is difficult to extrapolate how far this model can be used to compute realistic wind energetics on a continental or regional basis. While there is a lot of room for improvement, it is worth emphasizing that in our simple approach, and in contrast to more classical GCM studies, our results do not depend on parameterizations of convection (i.e. kinetic energy inputs) nor on parameterizations of the boundary layer (i.e. energy dissipation through drag coefficients). It is therefore very encouraging that our results are in agreement with these more detailed models.

Future, more complex versions of this model could give even better results. It would then provide an interesting tool for some climate studies such as available wind power, and the influence of large scale wind farms on Earth climate, for instance.

Acknowledgements. This work was funded by the CEA Energie program. The authors wish to thank Corentin Herbert, Bérangère Dubrulle, François Daviaud, Pierre Sepulchre, Masa Kageyama and Gilles Ramstein for fruitful discussions. The authors also express their thanks to Hannah Kohrs for language improvements.
ESDD

$6,407-433,2015$

Wind energetics with a MEP climate model

S. Karkar and D. Paillard

Title Page

Abstract

Introduction

Conclusions References

Tables

Figures

14

$>\mathbf{I}$

4

Back

Close

Full Screen / Esc

Printer-friendly Version

Interactive Discussion 


\section{References}

Gans, F., Miller, L. M., and Kleidon, A.: The problem of the second wind turbine - a note on a common but flawed wind power estimation method, Earth Syst. Dynam., 3, 79-86, doi:10.5194/esd-3-79-2012, 2012. 408

5 Gustavson, M. R.: Limits to wind power utilization, Science, 204, 13-17, 1979. 408

Herbert, C.: Applications de la mécanique statistique à la modélisation du climat, $\mathrm{PhD}$ thesis, Université Pierre et Marie Curie, Paris, France, Laboratoire des Sciences du Climat et de l'Environnement, CEA-Saclay, France, 2012. 418

Herbert, C., Paillard, D., Kageyama, M., and Dubrulle, B.: Present and last glacial maximum climates as states of maximum entropy production, Q. J. Roy. Meteorol. Soc., 137, 10591069, 2011. 409, 410, 417

Kanamitsu, M., Ebisuzaki, W., Woollen, J., Yang, S.-K., Hnilo, J. J., Fiorino, M., and Potter, G. L.: NCEP-DOE AMIP-II reanalysis (R-2), B. Am. Meteorol. Soc., 83, 1631-1643, 2002. 419

Lorenz, E. N.: Generation of available potential energy and the intensity of the general circulation, in: Dynamics of Climate, edited by: Pfeffer, R. L., Pergamon Press, Oxford, 1960. 409

Lorenz, R. D., Lunine, J. I., Withers, P. G., and MacKay, C. P.: Titan, Mars and Earth: entropy production by latitudinal heat transport, Geophys. Res. Lett., 28, 415-418, 2001. 409

Marques, C., Rocha, A., and Corte-Real, J.: Comparative energetics of ERA-40, JRA-25 and NCEP-R2 reanalysis, in the wave number domain, Dynam. Atmos. Oceans, 50, 375-399, 2010. 420

Marvel, K., Kravitz, B., and Caldeira, K.: Geophysical limits to global wind power, Nat. Clim. Change, 3, 118-121, doi:10.1038/nclimate1683, 2012. 408, 420, 421

Miller, L. M., Gans, F., and Kleidon, A.: Estimating maximum global land surface wind 25 power extractability and associated climatic consequences, Earth Syst. Dynam., 2, 1-12, doi:10.5194/esd-2-1-2011, 2011. 408, 420, 421

O'Brien, D. M. and Stephens, G. L.: Entropy and climate, II: Simple models, Q. J. Roy. Meteorol. Soc., 121, 1773-1796, 1995. 409

Onogi, K., Tsutsui, J., Koide, H., Sakamoto, M., Kobayashi, S., Hatsushika, H., Matsumoto, R., Ose, T., Mannoji, N., and Taira, R.: The JRA-25 reanalysis, J. Meteorol. Soc. Jpn., 85, 369-432, 2007. 420

ESDD

6, 407-433, 2015

Wind energetics with a MEP climate model

S. Karkar and D. Paillard

Title Page

Abstract

Introduction

Conclusions References

Tables

Figures

14

$>$ I

4

Back

Close

Full Screen / Esc

Printer-friendly Version

Interactive Discussion

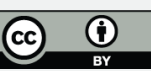


Ozawa, H., Ohmura, A., Lorenz, R. D., and Pujol, T.: The second law of thermodynamics and the global climate system: a review of the maximum entropy production principle, Rev. Geophys., 41, 1-23, 2003. 409

Paltridge, G.: Global dynamics and climate - a system of minimum entropy exchange, Q. J. Roy. Meteorol. Soc., 101, 475-484, 1975. 409

Trenberth, K. E. and Caron, J. M.: Estimates of meridional atmosphere and ocean heat transports, J. Climate, 14, 3433-3443, 2001. 418

Uppala, S. M., Kållberg, P. W., Simmons, A. J., Andrae, U., da Costa Bechtold, V., Fiorino, M., Gibson, J. K., Haseler, J., Hernandez, A., Kelly, G. A., Li, X., Onogi, K., Saarinen, S., Sokka, N., Allan, R. P., Andersson, E., Arpe, K., Balmaseda, M. A., Beljaars, A. C. M., van de Berg, L., Bidlot, J., Bormann, N., Caires, S., Chevallier, F., Dethof, A., Dragosavac, M., Fisher, M., Fuentes, M., Hagemann, S., Hólm, E., Hoskins, B. J., Isaksen, L., Janssen, P. A. E. M., Jenne, R., McNally, A. P., Mahfouf, J.-F., Morcrette, J.-J., Rayner, N. A., Saunders, R. W., Simon, P., Sterl, A., Trenberth, K. E., Untch, A., Vasiljevic, D., Viterbo, P., and Woollen, J.: The ERA-40 re-analysis, Q. J. Roy. Meteorol. Soc., 131, 2961-3012, 2005. 420

\section{ESDD}

6, 407-433, 2015

\section{Wind energetics with} a MEP climate model

\section{S. Karkar and D. Paillard}

Title Page

Abstract

Introduction

Conclusions References

Tables

Figures

14

$\Delta \mathbf{I}$

4

Back

Close

Full Screen / Esc

Printer-friendly Version

Interactive Discussion 

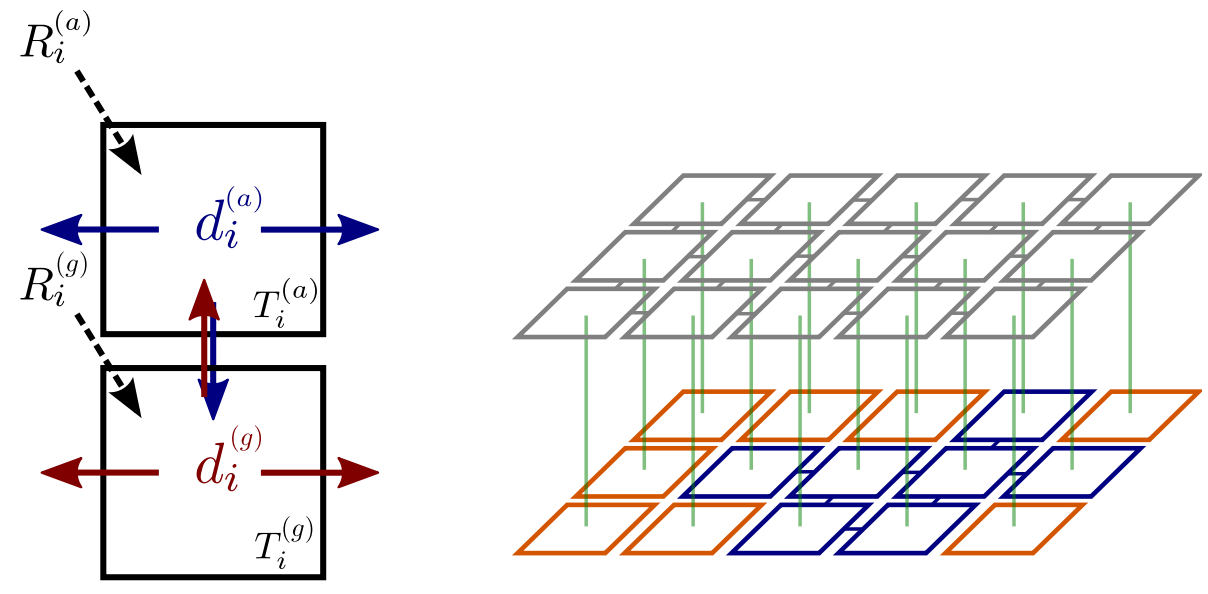

Figure 1. Left: vertical cut of the MEP model with an atmospheric cell on top of a ground cell. Energy fluxes are represented with arrows. Right: sample of the model grid, with full connectivity at the atmospheric level (grey cells), and limited connectivity at the ground level (blue cells: ocean, orange cells: continent). Connectivity between adjacent cells is figured with light lines (grey: atmospheric, blue: oceanic, green: vertical).

\section{ESDD}

$6,407-433,2015$

Wind energetics with a MEP climate model

S. Karkar and D. Paillard

Title Page

\section{Abstract}

Introduction

Conclusions References

Tables

Figures

14

I

4

Back

Close

Full Screen / Esc

Printer-friendly Version

Interactive Discussion

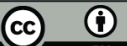




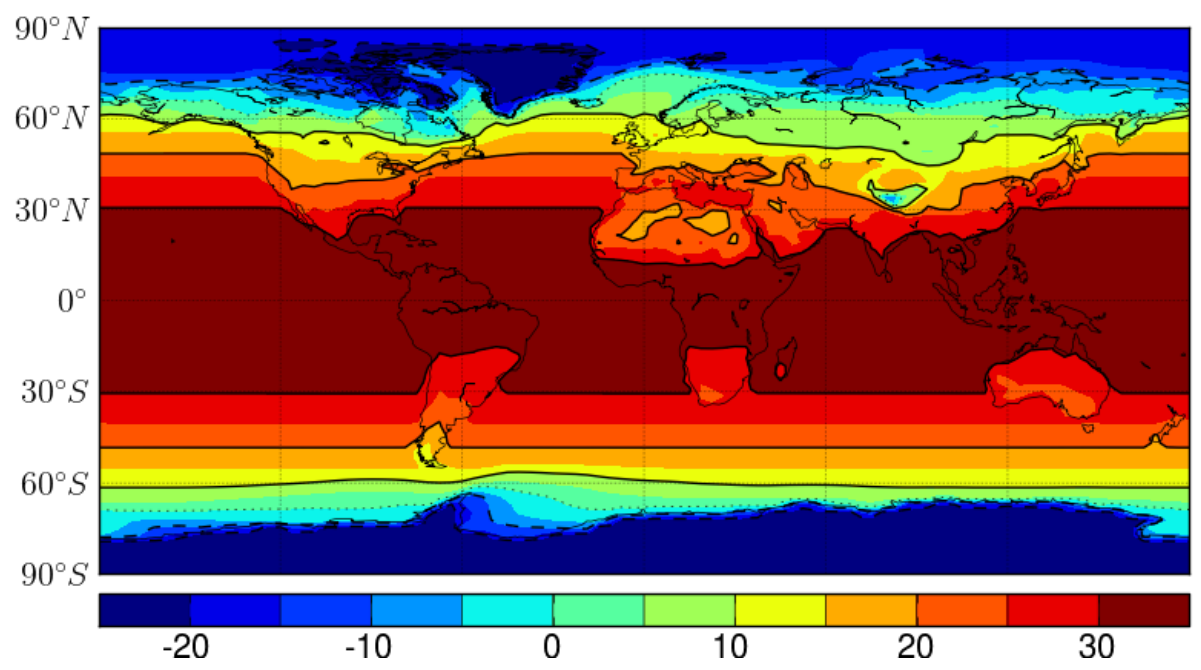

Figure 2. Temperature field (in ${ }^{\circ} \mathrm{C}$ ) on the surface layer of the grid $(72 \times 96)$, given by the MEP model. Input data (albedo, atmospheric composition, and insolation) and grid resolution are similar to that of the IPSL-CM4 model for pre-industrial conditions. Dotted lines are $0^{\circ} \mathrm{C}$ contours, plain lines are positive $10^{\circ} \mathrm{C}$ spaced contours, and dashed lines are negative $10^{\circ} \mathrm{C}$ spaced contours.

\section{ESDD}

$6,407-433,2015$

Wind energetics with a MEP climate model

S. Karkar and D. Paillard

\section{Title Page}

\begin{tabular}{|c|c|}
\hline Abstract & Introduction \\
\hline Conclusions & References \\
\hline Tables & Figures \\
\hline I & $\checkmark$ \\
\hline 4 & $\triangleright$ \\
\hline Back & Close \\
\hline Full Screen / Esc \\
\hline
\end{tabular}

Printer-friendly Version

Interactive Discussion

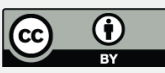




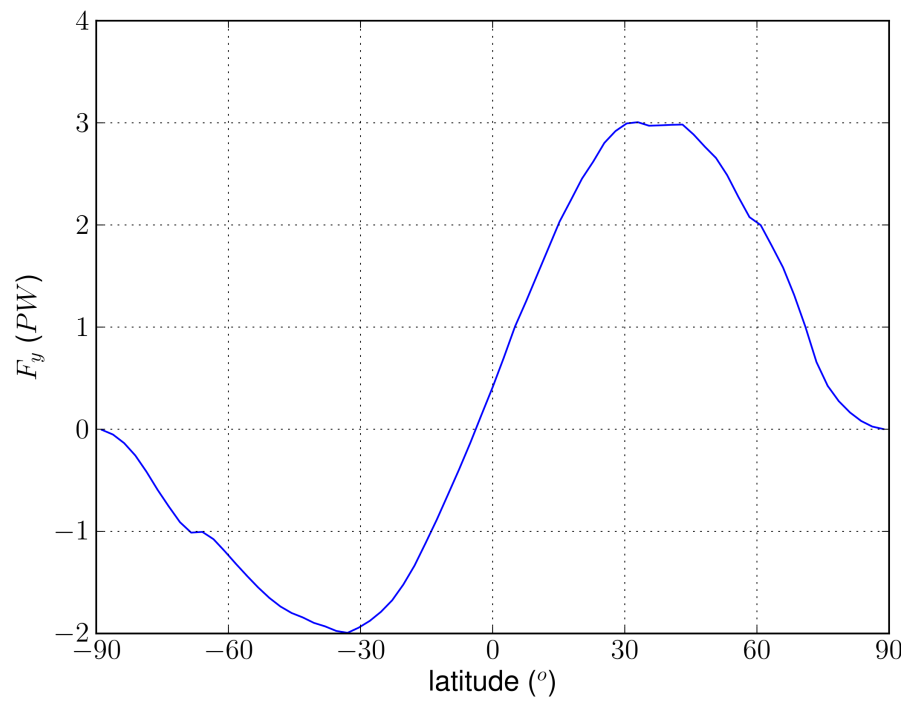

Wind energetics with a MEP climate model

S. Karkar and D. Paillard

Title Page

Abstract

Introduction

Conclusions References

Tables

Figures

14

D

4

Back

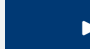

$>$

Close

Full Screen / Esc

Figure 3. Poleward meridional heat transported by the atmosphere, resulting from the MEP model $(72 \times 96$ grid $)$.

Printer-friendly Version

Interactive Discussion

(c) (i) 


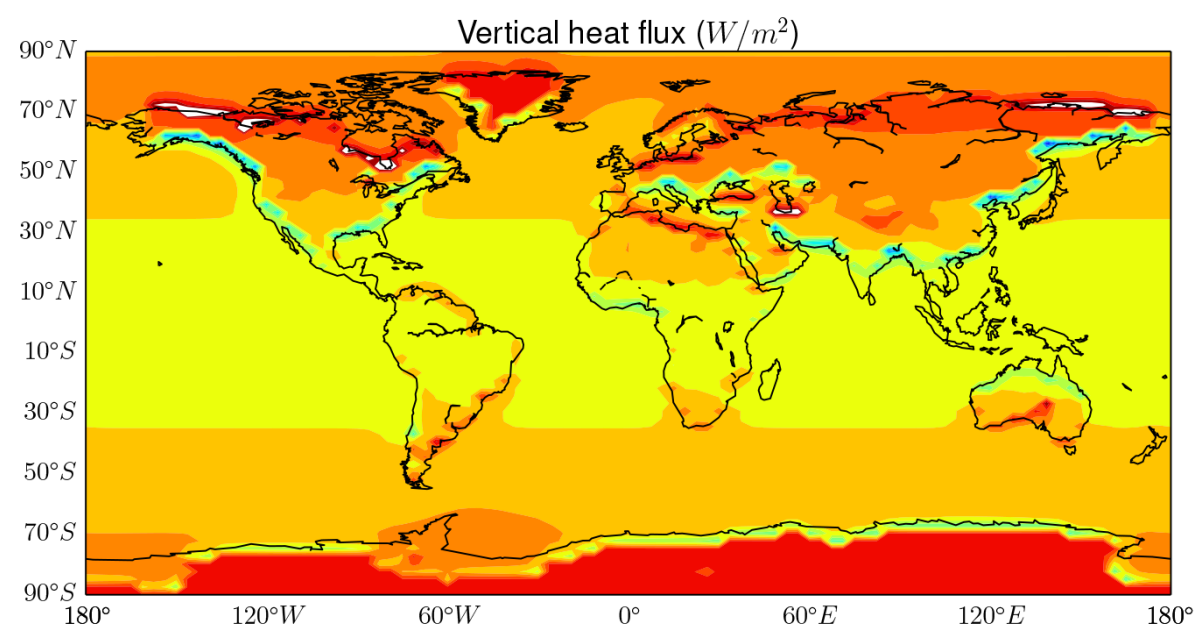

\section{ESDD}

6, 407-433, 2015

Wind energetics with a MEP climate model

S. Karkar and D. Paillard

Title Page

\begin{tabular}{|c|c|}
\hline Abstract & Introduction \\
\hline Conclusions & References \\
\hline Tables & Figures \\
\hline I4 & $\bullet \mathbf{I}$ \\
\hline 4 & $\triangleright$ \\
\hline Back & Close \\
\hline
\end{tabular}

Full Screen / Esc

Figure 4. Annual mean vertical heat flux from the atmosphere to the ground, resulting from the MEP model $(72 \times 96$ grid).

Printer-friendly Version

Interactive Discussion 


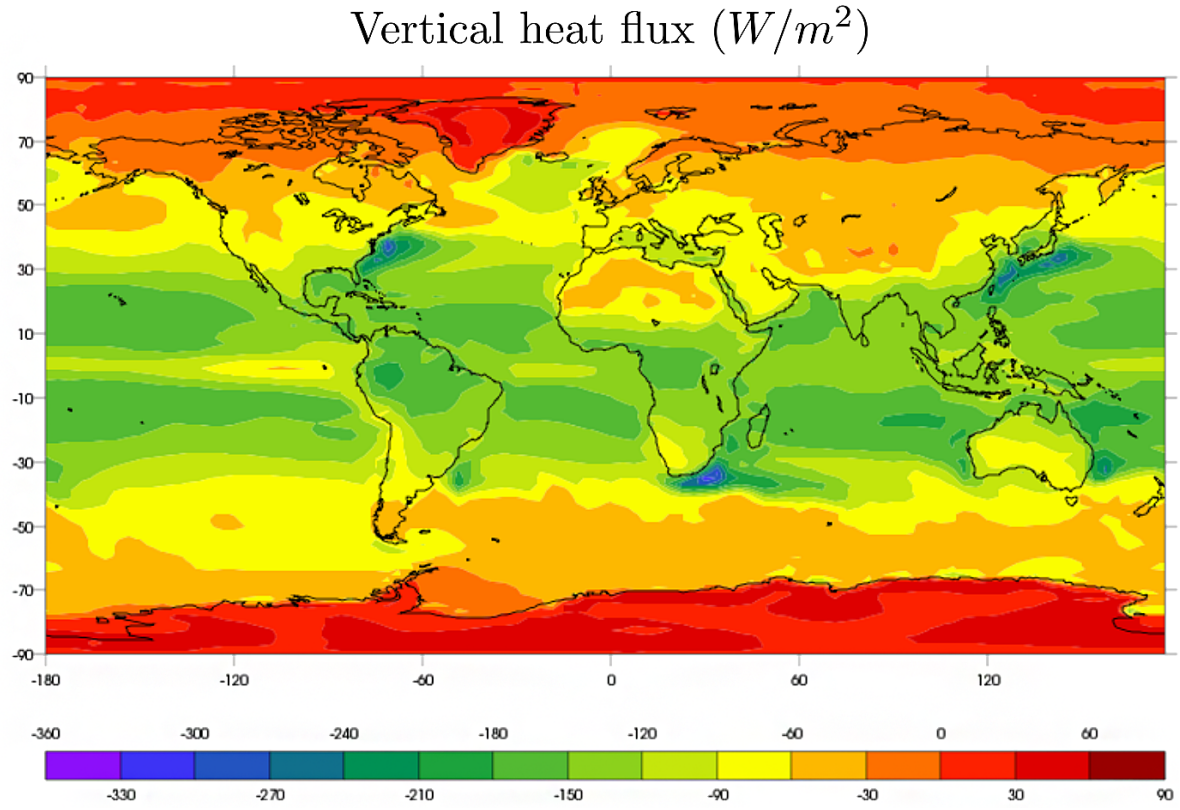

\section{ESDD}

$6,407-433,2015$

Wind energetics with a MEP climate model

S. Karkar and D. Paillard

Title Page

Abstract

Introduction

Conclusions References

Tables

Figures

14

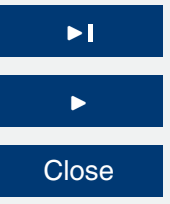

Back

Full Screen / Esc

Figure 5. Annual mean vertical heat flux from the atmosphere to the ground, resulting from the IPSL-CM5A model in pre-industrial conditions (96 × 95 grid, 39 vertical atm. levels).

Printer-friendly Version

Interactive Discussion

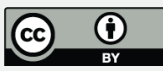




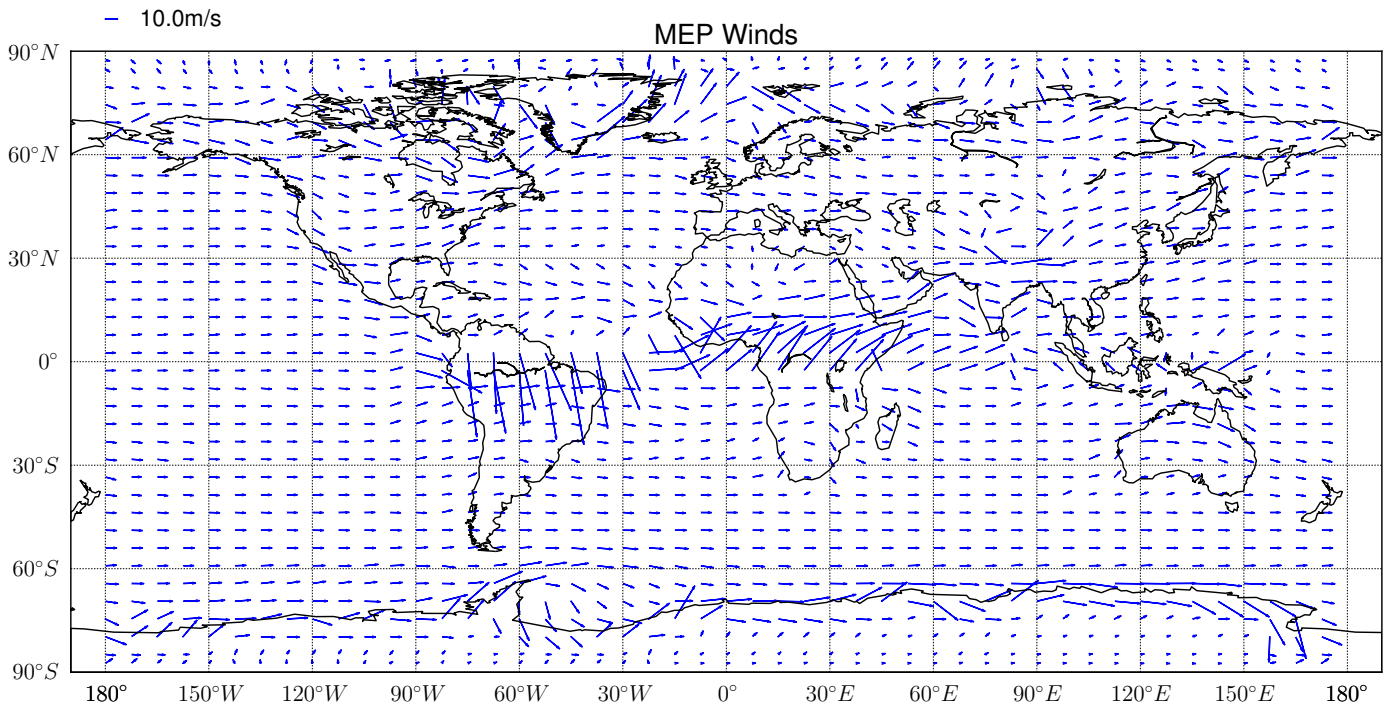

Figure 6. Annual mean wind vectors resulting from the quasi-geostrophic model and the flux inversion of the MEP model $(36 \times 48$ grid).

\section{ESDD}

$6,407-433,2015$

Wind energetics with a MEP climate model

S. Karkar and D. Paillard

Title Page

\section{Abstract}

Introduction

Conclusions References

Tables

Figures

14

$>1$

4

Back

Close

Full Screen / Esc

Printer-friendly Version

Interactive Discussion

(c) (1) 


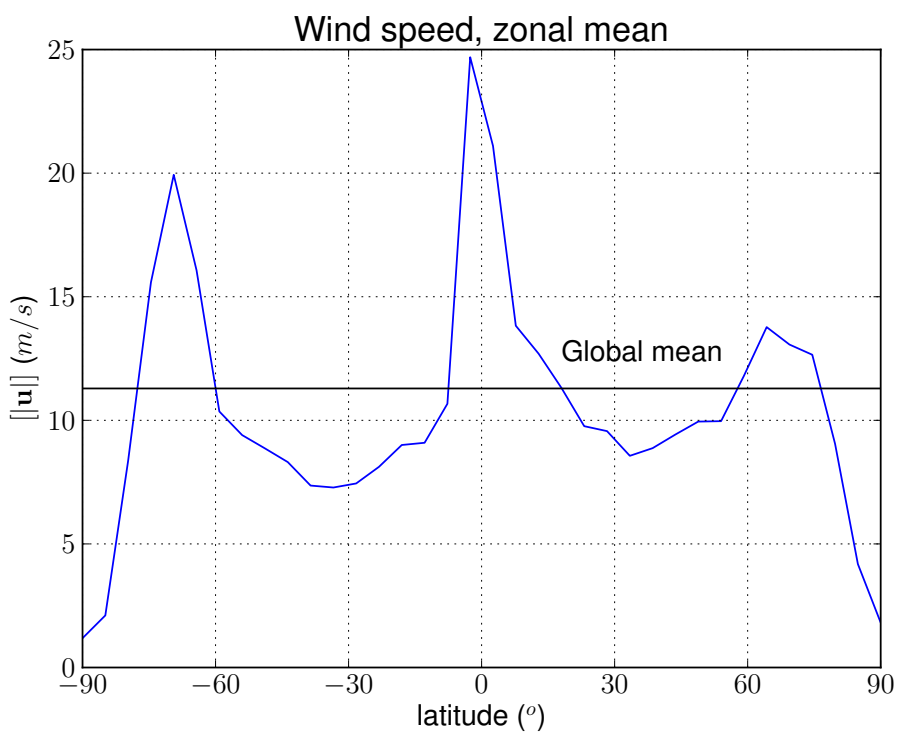

Figure 7. Zonal mean of the annual mean wind speed, resulting from the quasi-geostrophic model and the flux inversion of the MEP model ( $36 \times 48$ grid).

\section{ESDD}

6, 407-433, 2015

Wind energetics with a MEP climate model

S. Karkar and D. Paillard

\section{Title Page}

Abstract

Introduction

Conclusions References

Tables

Figures

14

DI

4

Back

Close

Full Screen / Esc

Printer-friendly Version

Interactive Discussion 


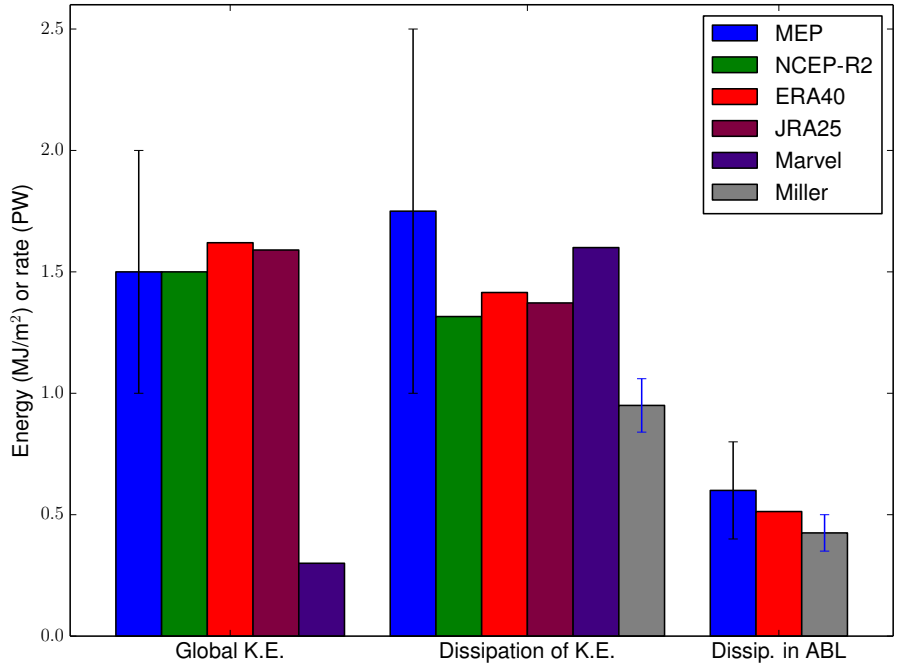

Figure 8. Comparison of MEP model wind energetics with reanalyses and other models.

\section{ESDD}

6, 407-433, 2015

Wind energetics with a MEP climate model

S. Karkar and D. Paillard

Title Page

Abstract

Introduction

Conclusions References

Tables

Figures

14

$>1$

4

Back

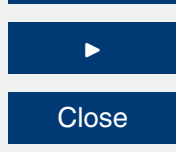

Full Screen / Esc

Printer-friendly Version

Interactive Discussion

(c) (i) 